\title{
Penapisan Bakteri Simbion Gastropoda Stramonita armigera Penghasil Senyawa Antibakteri Multi Drug Resistant dari Perairan Ternate
}

\author{
Delianis Pringgenies*) dan Mijil Ciptaning Dananjoyo \\ Jurusan Ilmu Kelautan, Fakultas Perikanan dan Ilmu Kelautan, Universitas Diponegoro, Semarang 50275 \\ Diterima 02-02-2010 Disetujui 03-12-2010
}

\begin{abstract}
Antibiotic resistance is an ability of bacteria to hold the antibiotic effect. It was reported that there is a humanpatogen bacteria that resistance to one or more classes of antibiotic. It become a problem on medical world. To solve those problems, it is necessary to search the new antibiotic compounds that more effective and efficient to solve the problem of Multi Drug Resistance (MDR). The secondary metabolite-producing marine invertebrates and symbiont microorganisms, have prospect as an antibiotic. The symbiont microorganisms may produce the secondary metabolite similar to their host. The aims of the reseach were to determinate of gastropods symbiont bacteria that capable of producing Antibacterial MDR (Multi Drugs Resistant) Compound. Sample of Molusc were collected from Ternate (Molucas) islands. Isolation of symbiotic bacteria, screening for bacteria which producing secondary metabolites as anti-MDR bacteria, antibacterial test, isolation of clinical pathogenic bacteria (MDR), conducting anti-bacterial sensitivity test, sensitivity test for antibacterial, DNA exctraction, DNA amplification based on PCR method, DNA sequencing. Result of 16S r-DNA sequence was then analyzed and edited using GENETYX program and followed by 16S rDNA sequence analysis. The result showed that 17 strains were isolated from gastropods Stramonita armigera. Antibacterial assays showed that TSA 8.7 isolate have ability to inhibit Pseudomonas sp., Escherichia coli dan Enterobacter sp. the molecular analyses showed that isolate TSA 8.7 closed by related to Vibrio sp. Strain JZDN1, with $98 \%$ of homology. Based on this experimental result, it could be concluded that gastropods-symbiont bacterium Stramonita armigera capable of producing antibacterial compound against strain Multi Drug Resistant (MDR). There is 11 isolates of gastropods-symbiont bacteria Stramonita armigera that have an antibacterial MDR activity.
\end{abstract}

Keywords: Antibacterial, Gastropods, Multi Drug Resistant, Symbion bacteria

\section{PENDAHULUAN}

Bahwa resistensi kuman terhadap antibiotik sudah merupakan problem diseluruh dunia baik di dalam rumah sakit atau di komunitas yang membutuhkan keseriusan dalam pengelolaan pasien dengan penyakit infeksi. Hal ini disebabkan karena penggunaan antibiotik/antimikroba yang tidak rasional/bijaksana yang dilakukan oleh prescribers (para dokter penulis resep) atau pasien sendiri. Bakteri yang telah mengalami resistensi terhadap beberapa jenis antibiotik dikenal dengan bakteri Multi Drug Resistant (MDR). Bakteri Multi Drug Resistant (MDR) telah menjadi salah satu permasalahan dalam dunia kesehatan yang sangat serius, maka perlu dilakukan pencarian senyawa antibiotik baru yang lebih efektif dan efisien dalam mengatasinya.

\footnotetext{
*Telp: +6281390800800

Email: pringgenies@yahoo.com
}

Di sisi lain, metabolit dari mikroorganisme mengalami perkembangan pesat karena adanya dugaan bahwa sejumlah senyawa bioaktif yang diperoleh dari hewan invertebrata juga dihasilkan oleh mikroorganisme yang berasosiasi dengannya. Diperkirakan kurang dari 2\% mikrobia baru berhasil diisolasi dari lingkungan laut sebagai kultur murni. Dilaporkan bahwa terdapat asosiasi mikroorganisme dengan organisme laut yang juga mensistesa metabolit sekunder seperti organisme inangnya (Watermann, 1999; Burgess et al., 2003).

Gastropoda merupakan salah satu kelas dari filum moluska yang memiliki kemampuan menghasilkan senyawa metabolit sekunder yang berpotensi sebagai senyawa antibiotik. Seperti yang dinyatakan Westley dan Benkendorff 2008, bahwa Gastropoda jenis Stramonita memiliki senyawa bioaktif Bromoindirubins yang memiliki aktivitas sebagai antikanker serta memiliki aktivitas antibakteri. Burgessa et al., (2003), 
menyatakan bahwa mikroorganisme yang bersimbiosis dengan organisme laut memiliki kemampuan mensintesa metabolit sekunder seperti inangnya.

Salah satu alternatif untuk mendapatkan senyawa bioaktif dari Gastropoda yakni dengan mengisolasi bakteri simbion dari gastropoda tersebut maka tujuan penelitian adalah determinasi bakteri simbion Gastropoda Stramonita armigera yang memiliki aktivitas antibakteri Multi Drug Resistant (MDR) dengan menggunakan PCR 16S rDNA.

\section{BAHAN DAN METODE}

Sampling. Moluska dikoleksi dari perairan pulau Bastiong Kepulauan Ternate, Maluku dengan cara pengambilan langsung dengan menggunakan seperangkat alat scuba diving pada kedalaman sekitar 3 meter. Sampel kemudian dimasukkan dalam tas plastik polietilin (Whir-pak, Nasco, USA) dan ditempatkan dalam cool boks. Selanjutnya dilakukan Isolasi bakteri, Skrining bakteri penghasil senyawa antiMDR, Uji antibakteri Gatropoda Stramonita armigera.

Isolasi Bakteri. Isolat bakteri hasil pengenceran dalam cawan petri dipurifikasi dengan metode goresan hingga diperoleh biakan murni (Brooks et al., 2001). Selanjutnya, skrining bakteri penghasil antibakteri MDR dilakukan dengan menggunakan metode overlay untuk uji kualitatif (Isnansetyo \& Kamei, 2003), dan metode difusi agar Kirby-Bauer untuk uji kuantitatif antibakteri MDR (Brooks et al., 2001). Inkubasi dilakukan selama 2x24 jam kemudian diamati dan diukur zona hambatan yang terbentuk. Uji kualitatif dilakukan untuk mengetahui terbentuk atau tidaknya zona hambatan sedangkan pengukuran zona hambatan dilakukan pada uji kuantitatif.

Skrining bakteri penghasil senyawa anti-MDR. Tes uji hambatan pertumbuhan dilakukan antara isolat bakteri dari moluska terhadap bakteri MDR dengan menggunakan metoda overlay. Setiap isolat dari moluska diinokulasikan ke permukaan medium agar. Sebanyak 12 isolat ditempatkan dalam 1 cawan petri. Petri tersebut diinkubasikan selama 4 hari pada suhu ruangan. Satu persen kultur ( $v / v$ ) dari setiap target bakteri MDR pada fase logaritma (ca. $10^{\circ} \mathrm{sel} \mathrm{ml-1)} \mathrm{dicampur}$ dengan soft agar yang kemudian dituangkan pada agar media yang telah diinokulasi isolat dari moluska sebelumnya. Petri diinkubasikan pada suhu ruang selama 48 jam. Aktivitas Anti-bakteri ditentukan oleh adanya formation zona hambatan di sekeliling isolat Gasropoda.

Isolasi bakteri patogen klinik (MDR). Berbagai spesimen klinis (darah,feses, urine dII) didapatkan dari Laboratorium Mikrobiologi Klinik, Rumah Sakit Kariadi/ FK UNDIP Semarang, dikultur pada medium Nutrient Agar, Mac Conkey dan medium Blood agar, CHROM agar $S$. aureus dan CHROM agar MRSA (ITK Diagnostic). Setelah 18-24 jam inkubasi pada suhu $37^{\circ} \mathrm{C}$. Identifikasi bakteri dilakukan dengan berbagai uji yakni: morfologi koloni bakteri, uji katalase, uji coagulase, gram stain, haemolisis dalam Blood agar, pink colony dalam $\mathrm{CHROM}$ agar $\mathrm{S}$. aureus dan $\mathrm{CHROM}$ agar MRSA media (gram positive bacteria), Mac Conkey agar plate (gram negative bacteria). Hasil bakteri MDR terdiri dari 6 strain bakteri MDR, yaitu :Klebsiella sp., Pseudomonas sp., Escherichia coli, Coagulase-Negative Staphylococcus, Enterobacteria strain 5 dan Enterobacteria strain 10.

Uji antibakteri Gasropoda. Jaringan Gasropoda dihancurkan dengan blender dan selanjutnya diekstraksi dengan cara homogenisasi dengan pelarut Hexane (non polar) dan $10 \%$ methanol dalam khloroform (polar) dengan menggunakan blender. Campuran organik yang diperoleh kemudian difiltrasi dengan menggunakan vacuum filter. Filtrat kemudian dipisahkan dari pelarut dengan menggunakan rotary evaporator. Selanjutnya ekstrak diujikan dengan strain MDR dengan metode difusi agar. Aktivitas antibakteri ditentukan dengan ada tidaknya zona hambatan yang terbentuk di sekeliling paper disk.

Pelaksanaan Inokulasi. Isolat bakteri disuspensi dalam air garam steril, sehingga turbiditas tampak mencapai 0.5 standar McFarland standard. Suspensi bakteri langsung digunakan untuk uji difusi.

Uji sensitifitas antibakteri. Isolat bakteri dalam cawan petri dipurifikasi dengan metode goresan hingga diperoleh biakan murni (Brooks et al., 2001). Selanjutnya, skrining bakteri penghasil antibakteri MDR dilakukan dengan menggunakan metode overlay untuk uji kualitatif dan metode difusi agar Kirby-Bauer untuk uji kuantitatif antibakteri MDR (Brooks et al., 2001). Inkubasi dilakukan selama 2x24 jam kemudian diamati dan diukur zona hambatan yang terbentuk. Uji kualitatif dilakukan untuk mengetahui terbentuk atau tidaknya zona hambatan sedangkan pengukuran zona hambatan dilakukan pada uji kuantitatif. 
Ekstraksi DNA. Isolat bakteri terpilih dikultur pada $50 \mathrm{ml}$ medium cair ZoBell $2216 \mathrm{E}$ pada suhu $20^{\circ} \mathrm{C}$ selama 24 jam, kemudian dipanen dengan sentrifugasi, dan selanjutnya dicuci dan disuspensi dengan akuades steril. Ekstraksi DNA dilakukan dengan mencampurkan $40 \mu \mathrm{l}$ suspensi bakteri, $10 \mu \mathrm{l}$ Proteinase $\mathrm{K}(1 \mathrm{mg} / \mathrm{ml})$ (Sigma Chemical Co, St. Louis, USA) dan $50 \mu \mathrm{l} 2 \mathrm{X}$ buffer. Campuran dipanaskan pada suhu $60^{\circ} \mathrm{C}$ selama 20 menit dan $100^{\circ} \mathrm{C}$ selama 10 menit. Setelah itu didinginkan secara cepat dalam es selama 10 menit dan disentrifugasi selama 5 menit pada $8000 \mathrm{rpm}$.

Amplifikasi DNA. Amplifikasi DNA dilakukan dengan metode PCR berdasarkan metode yang dilakukan oleh Radjasa et al., (2001). Primer yang digunakan adalah (Forward: 5'AGAGTTTGATCMTGGCTCAG-3' ; posisi 8-27 dan 1500 Reverse primer: 5'-GGTTACCTTGTTAC GACTT-3' ; posisi 1510-1492 berdasarkan penomoran 16S rRNA E. coli) menurut Weisburg et al., (1991). Amplifikasi DNA dengan PCR dilakukan dengan DNA thermal cycler (Mini cycler TM, MJ Research Inc, Watertown, MA, USA) dengan perlakuan temperatur sebagai berikut: Denaturasi awal pada $94^{\circ} \mathrm{C}$ selama 2 menit, kemudian 30 siklus denaturasi $\left(94^{\circ} \mathrm{C}\right.$ selama 2 menit), annealing $\left(45^{\circ} \mathrm{C}\right.$ selama 2 menit), dan ekstensi $\left(72^{\circ} \mathrm{C}\right.$ selama 2 menit), serta ekstensi terakhir pada $72^{\circ} \mathrm{C}$ selama 3 menit. Elektroforesis dilakukan dengan cara memasukkan $1 \mu$ alikuot produk PCR ke dalam sumur gel $1 \%$ gel agarosa yang diletakkan pada buffer 50X TAE, kemudian diamati apakah DNA telah teramplifikasi dengan baik.

Sekuensing DNA. Hasil amplifikasi dengan PCR dipurifikasi dan dikonsentrasikan dengan menggunakan Microcon-100 microconcentrator (Amicon, Beverly, MA, USA) menurut instruksi dari pabrik. Reaksi sekuen gen 16S rDNA disiapkan dengan menggunakan dengan menggunakan SequiTherm Long-Read Sequencing Kit (Epicentre Technologies, Madison, WI, USA).

Analisis sekuen 16S rDNA. Hasil sekuen 16S rDNA selanjutnya dianalisis dan diedit dengan menggunakan program GENETYX (Sabdono et al., 2000). Selanjutnya sekuen lengkap dari tiap isolat yang dipilih dibandingkan dengan sekuen DNA pada DNA database bank. Penelusuran dilakukan dengan sistem internet untuk memperoleh presentasi homologi dan untuk mengidentifikasi isolat. Selanjutnya studi filogenetik isolat dilakukan dengan menggunakan program CLUSTAL W (ver. 1,60) program. Pohon filogenetik selanjutnya akan dikonstruksi dengan menggunakan program PHYLIP.

\section{HASIL DAN PEMBAHASAN}

Isolasi Bakteri Simbion Gastropoda. Jumlah isolat bakteri yang diperoleh dari gastropoda Stramonita armigera ialah berjumlah 17 isolat bakteri, dimana isolat tersebut memiliki sifat koloni yang dibedakan berdasarkan; bentuk, dimana bentuk dari koloni yang ditemukan ialah tidak teratur, bulat, berbenang serta titik-titik; tepi, dimana tepi dari koloni yang ditemukan ialah berombak, berbenang, utuh serta keriting; permukaan, permukaan dari koloni yang ditemukan ialah rata dan serupa kawah; dan warna, dimana warna dari koloni yang ditemukan ialah putih, kuning, putih keruh serta putih transparan.

Uji Kualitatif Antibakteri MDR (Multi Drug Resistant). Berdasarkan hasil uji kualitatif Antibakteri MDR memperlihatkan bahwa dari 17 isolat bakteri simbion gastropoda Stramonita armigera yang didapatkan, ternyata hanya 11 isolat bakteri simbion gastropoda yang memiliki potensi menghasilkan senyawa antibakteri yang mampu menghambat pertumbuhan bakteri MDR secara kualitatif.

Uji Kuantitatif Antibakteri MDR (Multi Drug

Resistant). Hasil uji kuantitatif Antibakteri MDR dengan metode difusi agar berdasarkan prinsip Kirby-Bauer dan menggunakan kertas cakram yang berdiameter $8 \mathrm{~mm}$ memperlihatkan kemampuan daya hambat terhadap bakteri uji. Besarnya zona hambatan yang dibentuk maka terpilihlah satu isolat terbaik untuk uji lanjutan, yaitu isolat TSA 8,7 (Tabel. 1).

Identifikasi Bakteri. Hasil amplifikasi DNA dari isolat TSA 8,7 memperlihatkan hasil single band (pita tunggal) dengan ukuran sekitar 1500 bp (base pair) sesuai dengan pembanding menggunakan marker (penanda) DNA seperti yang terlihat pada Gambar. 1.

Hasil sekuen gen 16S rDNA dari isolat bakteri gastropoda terpilih dapat dilihat pada Tabel 2. Hasil penelusuran homologi sekuen 16S rDNA isolat TSA 8,7 dengan sekuen DNA database Gene Bank menggunakan sistem BLAST dapat dilihat pada Gambar 2. Sedangkan homologi isolat bakteri dengan bakteri dari database Gene Bank dapat dilihat pada Tabel 3.

Nilai kekerabatan hubungan antara isolat TSA 8,7 dengan sekuen pada data base yang sangat tinggi (> 
Tabel 1. Hasil Uji Kuantitatif antibakteri MDR Bakteri Stramonita armigera terhadap Bakteri MDR

\begin{tabular}{|c|c|c|c|c|c|c|}
\hline \multirow[b]{2}{*}{ Kode Isolat } & \multicolumn{6}{|c|}{ Diameter zona hambat (mm) } \\
\hline & Klebsiella & Pseudomonas & E.Coli & CNS & $\begin{array}{c}\text { Enterobacter } \\
5 \\
\end{array}$ & $\begin{array}{c}\text { Enterobacter } \\
10 \\
\end{array}$ \\
\hline TSA 8,1 & - & 9,23 & - & - & - & 8,66 \\
\hline TSA 8,2 & - & 9,63 & - & - & 9,95 & 8,56 \\
\hline TSA 8,3 & - & 8,63 & - & - & 9,22 & - \\
\hline TSA 8,4 & - & 8,90 & - & - & 9,53 & 8,62 \\
\hline TSA 8,5 & - & 10,29 & - & - & 9,59 & 8,78 \\
\hline TSA 8,6 & - & - & - & - & - & 8,88 \\
\hline TSA 8,7 & - & 11,59 & 9,01 & - & 9,71 & - \\
\hline TSA 8,8 & - & - & - & 12,91 & - & - \\
\hline TSA 8,9 & - & - & - & - & - & 8,77 \\
\hline TSA 8,10 & - & - & - & - & - & - \\
\hline TSA 8,11 & - & - & - & - & - & - \\
\hline TSA 8,12 & - & - & - & - & - & - \\
\hline TSA 8,13 & - & - & - & - & - & - \\
\hline TSA 8,14 & - & 13,53 & 8,64 & - & - & - \\
\hline TSA 8,15 & - & 10,95 & 8,82 & - & - & - \\
\hline TSA 8,16 & - & - & - & - & - & - \\
\hline TSA 8,17 & - & - & - & - & - & - \\
\hline
\end{tabular}

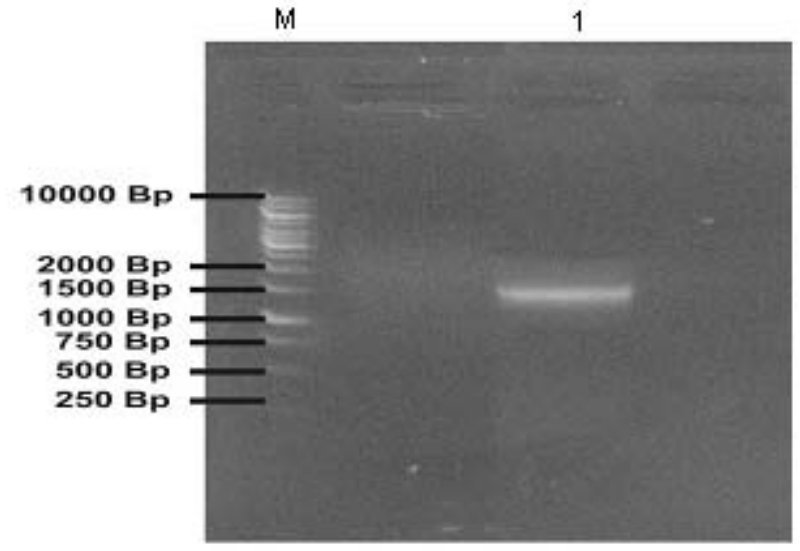

A

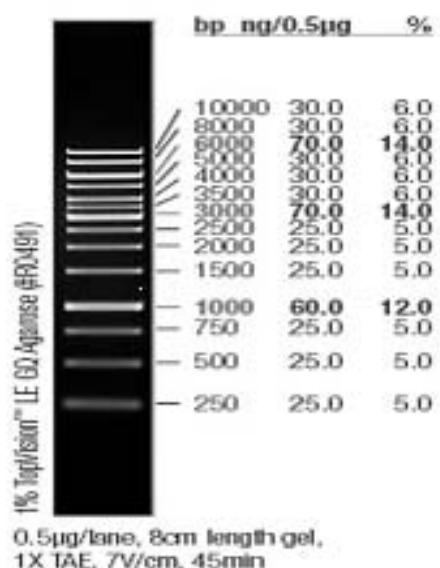

$1 \times$ TAE. 7 V $/ \mathrm{cm}$. $45 \mathrm{~min}$

$\mathrm{B}$

Gambar 1. Hasil Amplifikasi Gen 16S rDNA TSA 8.7 (M: DNA Marker, 1: Isolat TSA 8.7) (A); DNA Marker (B)

Tabel 2. Sekuen dari Isolat Bakteri Simbion Gastropoda

\begin{tabular}{cc}
\hline Isolat & Sekuen \\
\hline TSA & AGGGGTCGTATCTGGTCCAGGGGGCCGCCTTCGCCACCGGTATTCCTTCAGATCTCTACGCATTTCACCGCTACACC \\
8,7 & TGAAATTCTACCCCCCTCTACAGTACTCTAGTCTGCCAGTTTCAAATGCTATTCCGAGGTTGAGCCCCGGGCTTTCAC \\
& ATCTGACTTAACAAACCACCTGCATGCGCTTTACGCCCAGTAATTCCGATTAACGCTCGCACCCTCCGTATTACCGCG \\
& GCTGCTGGCACGGAGTTAGCCGGTGCTTCTTCTGTCGCTAACGTCAAATAAAG \\
\hline
\end{tabular}

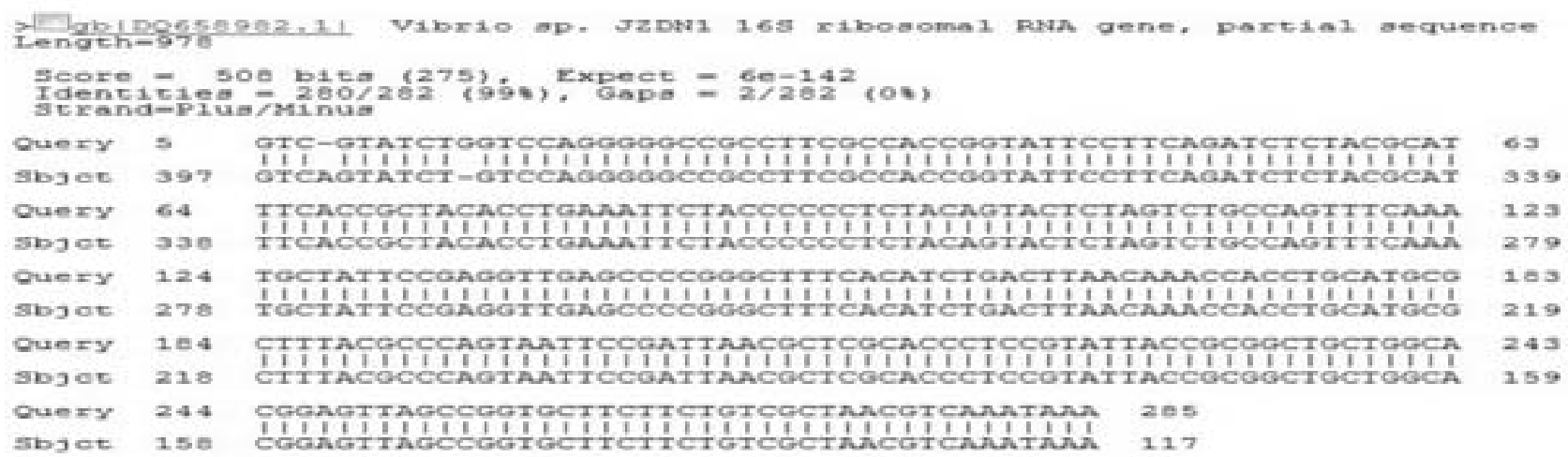

Gambar 2. Hasil Penelusuran Homologi Sekuen 16S rDNA Isolat TSA 8.7 dengan Sekuen DNA Database Gene Bank Menggunakan Sistem

Tabel 3. Homologi BLAST dari Isolat Bakteri Simbion Gastropoda

\begin{tabular}{clccc}
\hline No. & Isolat & Kemiripan relatif & Homologi (\%) & Nomor akses \\
\hline 1 & TSA 8,7 & Vibrio sp. JZDN1 & 98 & DQ658982,1 \\
\hline
\end{tabular}


95\%) menunjukkan bahwa paling tidak identifikasi molekuler ini mendekati kebenaran pada tingkat genus.

Berdasarkan uji kualitatif (antibakteri MDR) diperoleh 11 isolat bakteri simbion yang mampu menghambat aktivitas bakteri uji, isolat-isolat tersebut ialah isolat TSA 8,1, TSA 8,2, TSA 8,3, TSA 8,4, TSA 8,5, TSA 8,6, TSA 8,7, TSA 8,8, TSA 8,9, TSA 8,14 dan TSA 8, 15. Aktivitas antibakteri MDR diperlihatkan dengan terbentuknya zona hambat yang tampak sebagai daerah bening yang berada disekitar paper disk. Hasil ini membuktikan bahwa isolat-isolat bakteri tersebut memiliki potensi menghasilkan senyawa antibakteri dengan menghambat pertumbuhan bakteri uji. Penghambatan pertumbuhan bakteri uji tersebut dapat terjadi dikarenakan beberapa faktor, antara lain ialah adanya persaingan sebagai usaha dalam mendapatkan ruang dan nutrisi antara isolat bakteri simbion dengan bakteri uji serta adanya sistem pengeluaran metabolit sekunder yang dikeluarkan oleh isolat bakteri simbion. Dwidjoseputro (1988), menyatakan bahwa apabila dua spesies yang bersaingan ditumbuhkan pada tempat yang sama, maka spesies yang satu akan menghasilkan suatu senyawa yang dapat meracuni spesies yang lain, sehingga pertumbuhan spesies tersebut akan terganggu. Bakteri akan mengembangkan mekanisme pertahanan diri untuk menghadapi sesuatu yang mengancam kelangsungan hidupnya. Salah satu ancaman tersebut ialah perubahan kondisi lingkungan akibat kehadiran zat/senyawa asing (Conseption et al., 1994, dalam Sabdono et al., 2006).

Kemampuan dari tiap-tiap isolat bakteri simbion dalam menghambat pertumbuhan bakteri uji berbedabeda (Tabel 1). Diketahui bahwa terdapat 4 isolat bakteri simbion yang mampu menghambat 3 bakteri uji yaitu, TSA 8,2, TSA 8,4, TSA 8,5 dan TSA 8,7; terdapat 4 isolat bakteri simbion yang mampu menghambat 2 bakteri uji yaitu, TSA 8,1, TSA 8,3, TSA 8,14 dan TSA 8,15 ; dan terdapat 3 isolat bakteri simbion yang mampu menghambat 1 bakteri uji yaitu, TSA 8,6, TSA 8,8 dan TSA 8,9. Kemampuan suatu isolat bakteri simbion dalam menghambat lebih dari satu jenis bakteri uji dapat terjadi karena isolat bakteri simbion tersebut mampu menghasilkan suatu senyawa bioaktif yang memiliki kemampuan dalam menghambat beberapa jenis bakteri. Sedangkan untuk isolat bakteri simbion yang hanya mampu menghambat satu jenis bakteri uji hal tersebut dapat terjadi karena senyawa bioaktif yang dihasilkan isolat bakteri tersebut hanya mampu menghambat satu jenis bakteri saja. Senyawa

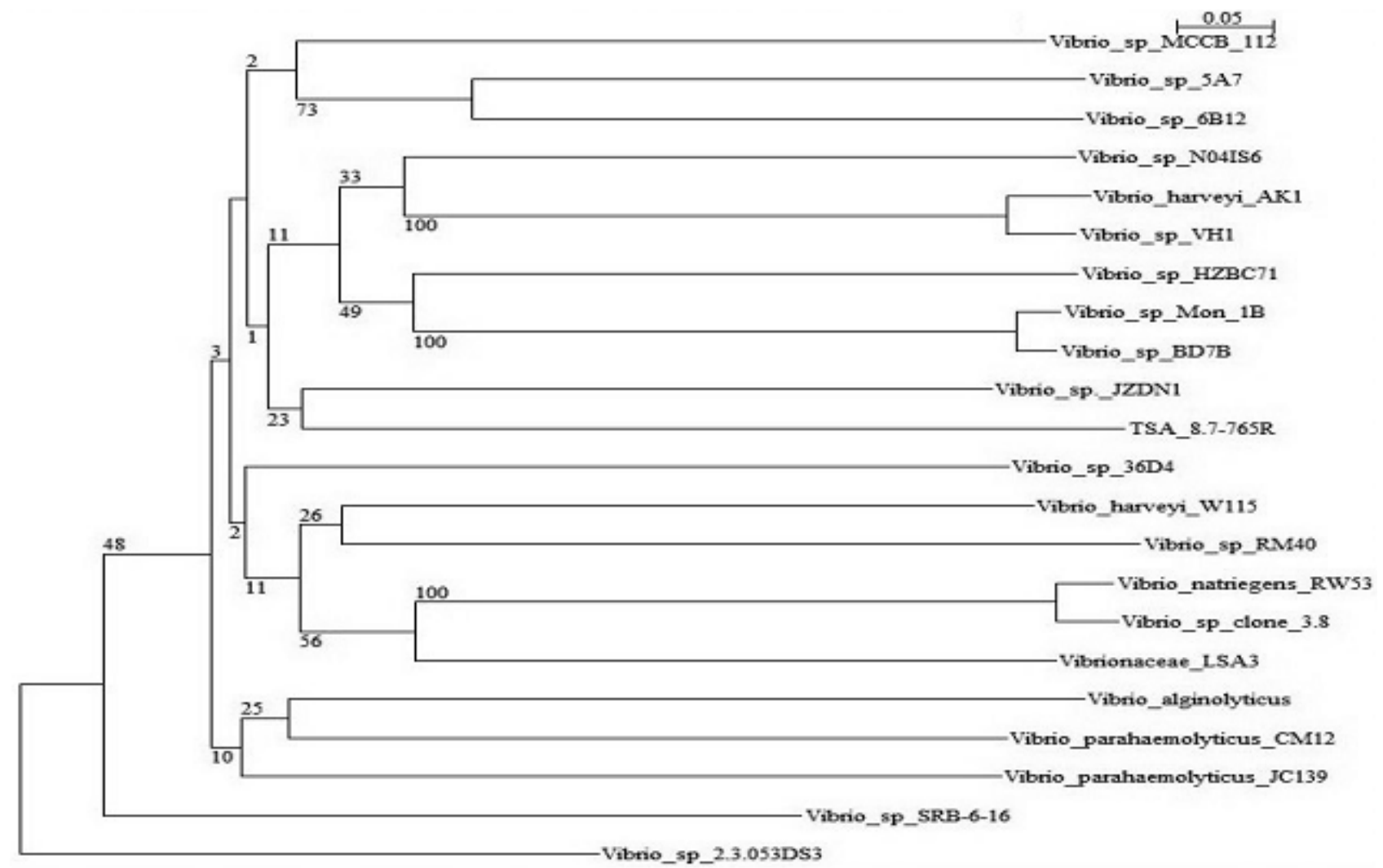

Gambar 3. Pohon Filogenetik yang Menunjukkan Kekerabatan Terdekat Antara Isolat TSA 8.7 dengan Bakteri Vibrio sp. JZDN1dengan Menggunakan Program Tree View 
antibakteri yang dihasilkan oleh bakteri memiliki sifat selektif dalam menghambat pertumbuhan bakteri lain, hal tersebut memungkinkan suatu bakteri dapat menghambat pertumbuhan bakteri lain, namun bakteri tersebut tidak dapat menghambat pertumbuhan dari jenis bakteri yang lainnya. Menurut Levinson (2004), senyawa antibakteri kisaran luas (broad spectrum antibacterial) ialah senyawa antibakteri yang mampu membunuh berbagai jenis mikroorganisme, sedangkan antibakteri kisaran sempit (narrow spectrum antibacterial) ialah senyawa antibakteri yang mampu mematikan hanya beberapa jenis mikroorganisme.

Berdasarkan hasil seleksi, isolat terpilih adalah isolat TSA 8,7 karena isolat tersebut memiliki kemampuan dalam menghambat 3 bakteri uji yaitu Pseudomonas sp., E. Coli, dan Enterobacteria sp strain 5 dengan diameter zona hambat secara berurutan untuk ketiga bakteri uji ialah $11,59 \mathrm{~mm} ; 9,01 \mathrm{~mm}$; dan 9,71 $\mathrm{mm}$.

Hasil amplifikasi 16SrDNA dari isolat TSA 8,7 menunjukkan bahwa isolat tersebut menghasilkan single band (pita tunggal) dengan ukuran sekitar 1500 bp sesuai dengan pembanding menggunakan marker DNA (Gambar. 1). Besarnya ukuran ini sesuai dengan yang diharapkan dari gen-gen 16S rDNA bakteri. Sabdono (2001), dalam Sabdono et al., (2006), menyatakan bahwa amplifikasi DNA dari isolat bakteri yang memiliki pita tunggal menunjukkan bahwa primer yang digunakan ialah primer spesifik untuk mengamplifikasi gen 16S rDNA pada bakteri. Amplifikasi 16S rDNA telah menjadi standar untuk mempelajari filogenetik dan keanekaragaman dari mikroorganisme laut.

Penelusuran pada DNA database Gen Bank menggunakan sistem BLAST melalui situs National Center for Biotechnology Information, National Institute for Health, USA (http://www.ncbi.nlm.nih.gov) memperlihatkan bahwa isolat TSA 8,7 memiliki homologi sebesar $98 \%$ dengan bakteri Vibrio sp. JZDN1. Hagström et al., (2000), menyatakan bahwa isolat yang memiliki persamaan sekuen $16 \mathrm{~S}$ rDNA lebih dari $97 \%$ dapat mewakili spesies yang sama. Sedangkan persamaan sekuen antara $93 \%-97 \%$ dapat mewakili identitas bakteri pada tingkat genus tetapi berbeda spesies. Berdasarkan pernyataan tersebut dapat dinyatakan bahwa isolat TSA 8,7 adalah spesies Vibrio sp. JZDN1 dengan homologi sekuen 98\%.
Bakteri Vibrio sp. JZDN1 merupakan kelompok bakteri dari filum Proteobacteria, kelas Gammaproteobacteria, ordo Vibrionales, family Vibrionaceae, genus Vibrio dan Spesies Vibrio sp. JZDN1 (http://www.ncbi.nlm.nih.gov).

Beberapa peneliti telah menemukan bahwa beberapa jenis bakteri Vibrio sp. yang ditemukan bersimbiosis dengan invertebrata laut mampu menghasilkan senyawa metabolit sekunder diantaranya ialah Vibrio sp. yang bersimbiosis dengan sponge Dysidea sp. mampu memproduksi senyawa brominated biphenyl ethers, Vibrio spp. pada sponge yang sama memproduksi senyawa Synthesize citotoxid dan Antibacterial tetrabromodiphenyl ethers (Elyakov et al., 1991, dalam Lee et al., 2001; Webster et al., 2001). Kemudian Oclarit et al., (1994), dalam Lee et al., (2001), menambahkan bahwa Vibrio sp. memproduksi senyawa anti-Bacillus peptide andrimid seperti yang ditemukan pada ekstrak sponge Hyatella sp. Selain itu Umemoto et al., (2008), melaporkan bahwa Vibrio sp. XY-214 mampu menghasilkan senyawa â-1,3-xylanase yang berguna untuk memproduksi D-xylose, yang merupakan sumber pembuatan xylitol dan bioethanol. Vibrio sp. strain NM 10 yang diisolasi dari Leiognathus nuchalis dari perairan jepang memiliki aktivitas dalam menghambat Pasteurella piscicida K-III penyebab penyakit ikan pasteurellosis pada ikan laut (Sugita et al., 1997).

\section{KESIMPULAN}

Berdasarkan hasil penelitian dapat disimpulkan bahwa dari 17 isolat bakteri yang diisolasi dari Gastropoda Stramonita armigera didapatkan 11 isolat bakteri yang memiliki aktivitas antibakteri terhadap bakteri MDR dan isolat TSA 8.7 memiliki aktivitas antibakteri terbaik dibandingkan dengan isolat lainnya karenai dapat menghambat 3 jenis bakteri MDR yakni bakteri Pseudomonas, E. Colidan Enterobacter 5. Hasil identifikasi dari isolat bakteri terpilih menunjukkan bahwa isolat TSA 8.7 memiliki kesamaan terhadap jenis Vibrio sp. JZDN1 dengan homologi 98\%.

\section{UCAPAN TARIMA KASIH}

Penelitian dibiayai oleh Program Insentif Riset Dasar-Dewan Riset Nasional-Kementerian Negara Riset, 2008. Ucapan terima kasih disampaikan kepada Dr. Ocky K Radjasa dan Dr. Adus Sabdono MSc (Jurusan IImu Kelautan FPIK Universitas Diponegoro 
Semarang), Sukrasno, Ph D (Sekolah Farmasi ITB Bandung) dan Endang Sri Lesatari, MD (Laboratorium Mikrobiologi Klinik, Fakultas Kedokteran UNDIP Semarang).

\section{DAFTAR PUSTAKA}

Brooks, G.F., Butel, J.S. \& Morse, S.A. 2001. Mikrobiologi Kedokteran. Penerbit Salemba Medika, Jakarta, 528 hlm.(diterjemahkan oleh Eddy).

Burgessa, J.G., Boyda, K.G., Amstronga, E., Jianga, Z., Yana, L., Berggrenb, M., Mayb, U., Pisacanec, T., Granmob, A.K. \& Adamsd, D.R. 2003. The Development of a Marine Natural Product-based Antifouling Paint. Biofouling, 2003. 19: 197-205.

Dwidjoseputro, D. 1989. Dasar-dasar Mikrobiologi. Djambatan, Jakarta, $188 \mathrm{hlm}$.

Hagström, A., Pinhassi, J. \& Zweifel, U.L. 2000 Biogeographical Diversity Among Marine Bacterioplankton. Aquat. Microb. Ecol. 21: 231-244.

Kelecom, A. 2001. Secondary Metabolites from Marine Microorganism. Ann. raz. Acad. Sci. 74(1): 151-170.

Kumar Jha, R. \& Xu Zi-rong. 2004. Biomedical Compounds from Marine organisms. Mar. Drugs. 2:123-146.
Lee, Y.K., Lee, J.H \& Lee, H.K. 2001. Microbial Symbiosis in Marine Sponges. J. Microbiol. 39(4): 254-264.

Leone, S., Silipo, A. Nazarenko, E.L., Lanzetta, R., Parrilli, M. \& Molinaro, A. 2007. Molecular Structure of Endotoxins from Gram-negative Marine Bacteria: An Update, Mar. Drugs. 5: $85-112$.

Levinson, W. 2004. Medical Microbiology and Immunology. Eight edition. McGraw-Hill, New York.

Sabdono, A., Radjasa, O.K.T., \& Bachtiar. 2006. Eksplorasi Senyawa Bioaktif Antifoulant Bakteri yang Berasosiasi dengan Avertebrata Laut Sebagai Alternatif Penanganan Biofouling di Laut. [Lap. Pen. HB. XII/II]. Pusat Studi Pesisir Dan Laut Tropis, Universitas Diponegoro, Semarang, $46 \mathrm{hlm}$.

Sugita, H., Matsuo, N., Hirose, Y., Iwato, M. \& Deguchi, Y. 1997. Vibrio sp. Strain NM 10, Isolated from the Intestine of a Japanese Coastal Fish, Has an Inhibitory Effect against Pasteurella piscicida. App. Env. Microbiol. (63).

Webster, N.S., Wilson, K.J., Blackall, L.L. \& Hill, R.T. 2001. Phylogenetic Diversity of Bacteria Associated with the Marine Sponge Rhopaloides odorabile. Appl. Environ. Microbiol. 67(1): 434-444.

Watermann, B. 1999. Alternative antifoulant techniques present and future. LimnoMar: 1-6. 